Théologiques

Théologiques

\title{
1 Corinthiens et l'archéologie : douze dossiers-test
}

\section{Daniel Gerber}

Volume 21, numéro 1, 2013

\section{L’archéologie et la Bible}

URI : https://id.erudit.org/iderudit/1025475ar

DOI : https://doi.org/10.7202/1025475ar

Aller au sommaire du numéro

\section{Éditeur(s)}

Faculté de théologie et de sciences des religions, Université de Montréal

\section{ISSN}

1188-7109 (imprimé)

1492-1413 (numérique)

Découvrir la revue

\section{Citer cet article}

Gerber, D. (2013). 1 Corinthiens et l'archéologie : douze dossiers-test.

Théologiques, 21(1), 213-245. https://doi.org/10.7202/1025475ar

\section{Résumé de l'article}

Quel profit y a-t-il à interroger l'archéologie pour commenter la première lettre de Paul aux Corinthiens, alors même que les communautés pauliniennes des premiers temps n'ont pas laissé de traces visibles de leur existence? Une reprise critique de douze dossiers-test, s'appuyant entre autres sur les actes de travaux interdisciplinaires publiés en 2005 et en 2010, tente de répondre à cette question relancée en 1983 par Jerome Murphy O'Connor. Si l'éclairage qu'apporte l'archéologie sur l'épître envoyée à ceux qui construisaient leur identité en Christ dans la cité isthmique vers le milieu du premier siècle est le plus souvent indirect, son apport est cependant loin d'être négligeable, dans la mesure où cette discipline s'intéresse aujourd'hui également au quotidien des petites gens. 


\title{
1 Corinthiens et l'archéologie: douze dossiers-test*
}

\author{
Daniel GeRbeR* * \\ Exégèse du Nouveau Testament \\ Université de Strasbourg (France)
}

Saccagée en 146 avant notre ère par les troupes du général romain Lucius Mummius, la ville de Corinthe a vécu au ralenti un siècle durant avant de connaître un nouvel essor à partir de 44 avant notre ère sous le nom de Colonia Laus Iulia Corinthiensis. Après avoir retrouvé sa superbe dans son habillage romain — ce que Paul a pu constater —, la cité isthmique a éprouvé bien des vicissitudes au cours des siècles. C'est en 1858, à la suite d'un violent tremblement de terre, que la décision a été prise de construire la «nouvelle Corinthe» quelques kilomètres plus loin sur la rive du Golfe. L'opportunité inespérée s'offrait ainsi aux archéologues de fouiller le site historique de l'«ancienne Corinthe ». Entamées en 1896, les fouilles à l'intérieur du périmètre délimité par les murs de la cité antique sont depuis conduites par l'École américaine d'études classiques d'Athènes (LangridgeNoti 1996; Williams II et Bookidis 2003). Faut-il le préciser? Ce vaste chantier n'a pas été entrepris dans le but prioritaire de retrouver des traces de la mission paulinienne ${ }^{1}$. Au fur et à mesure de son avancée, il a toutefois

* Texte d'une conférence présentée lors du 69e congrès de l'ACÉBAC (Association catholique des études bibliques au Canada) tenu à Pierrefonds, du 5 au 7 juin 2012.

* Daniel Gerber est professeur en exégèse néotestamentaire à la Faculté de théologie protestante de l'Université de Strasbourg (France). Il prépare actuellement un commentaire sur 1 Corinthiens pour les éditions Labor et Fides à Genève. Il a récemment publié (2008), "Il vous est né un Sauveur ». La construction du sens sotériologique de la venue de Jésus en Luc-Actes, Genève, Labor et Fides (Le Monde de la Bible 58).

1. Baslez $(2010,32)$ rappelle «le manque de visibilité des communautés pauliniennes aux trois premiers siècles, du point de vue de l'archéologie ». Si, pour Furnish (1988, 26), "a number of Christian gravestones from the latter half of the fourth century constitute the earliest archaeological evidence of a Christian presence in Corinth ", Sanders (2005b, 441-442) estime pour sa part que «hard archaelogical evidence for Christian worship, such as Christian decoration on lamps, basilicas, and recognizable

(C) Revue Théologiques 2013. Tout droit réservé. 
permis de se faire une idée plus précise du contexte dans lequel les premiers Corinthiens ont construit leur identité en Christ.

Parmi les études marquantes qui se sont appuyées sur l'archéologie pour éclairer certaines pages de la première lette de Paul aux Corinthiens, on compte bien entendu l'ouvrage de Jerome Murphy O'Connor (2004), publié en français sous le titre: Corinthe au temps de saint Paul. L'archéologie éclaire les textes ${ }^{2}$. En introduction à la troisième partie, l'auteur indique vouloir «attirer l'attention sur trois points sur lesquels la contribution de l'archéologie est particulièrement importante». S'il s'intéresse avant tout " [aux] dimensions et [à] la disposition des maisons, des temples et des boutiques ", c'est parce qu'il pense y déceler "des facteurs qui ont exercé une influence considérable sur la formation des églises-maisons, sur les problèmes posés par les repas pris dans des temples païens, et sur la façon dont Paul a exercé son apostolat» (Murphy O’Connor 2004, 221). Les discussions suscitées par cet essai stimulant et d'autres encore nous poussent toutefois à revisiter la question: que peut-on raisonnablement espérer tirer de l'archéologie et jusqu'où convient-il de dialoguer avec elle pour mieux comprendre 1 Co en particulier?

Deux ouvrages collectifs, fruits d'une collaboration interdisciplinaire récente - intitulés, l'un: Urban Religion in Roman Corinth. Interdisciplinary Approaches (Schowalter et Friesen 2005), et l'autre: Corinth in Context. Comparative Studies on Religion and Society (Friesen et al. $2010)^{3}$ - , donnent d'intéressantes réponses critiques à cette interrogation. En rappelant entre autres qu'une exploitation «constructive et responsable» des rapports archéologiques suppose une certaine familiarité avec leur «caractère interprétatif ", l'un des éditeurs, Daniel N. Schowalter (2010, 327 et 332, n. 13), s'inscrit dans la ligne de Richard E. Oster qui, dans un article au titre éloquent publié en 1992 — «Use, Misuse and Neglect of Archeological Evidence in Some Modern Works on 1 Corinthians" plaidait déjà pour un usage «responsable» et «approprié »(Oster 1992, 53) des découvertes faites sur le terrain.

Christian burial practicies, all appear no earlier and plausibly much later than ca. 475 ».

2. L'original, publié en anglais, a paru pour la première fois en 1983. Il a été revu et augmenté en 1992 et en 2001.

3. Au moment où nous rédigeons ce texte, les actes du colloque qui s'est tenu à Austin en 2010 sur le thème "Corinth in Contrast: Studies in Inequality " n'ont pas encore été publiés. 
Ce dialogue interdisciplinaire entre archéologues et exégètes de métier est d'autant plus appréciable que, depuis «les années 1960 et 1970 », les premiers ne se contentent plus seulement «de dégager, de dater et d'interpréter les données", mais s'interrogent aussi "sur les types d'informations qu'elles transmettent» (Schnapp 2009, 35). C'est ce que confirme Guy D.R. Sanders, actuellement directeur des fouilles de Corinthe, lorsqu'il souligne l'intérêt accru depuis cette période pour le savoir que l'on peut tirer des découvertes archéologiques en ce qui concerne la vie quotidienne des habitants de la cité ${ }^{4}$. Si «la fouille archéologique [...] n'est qu'une première étape dans un travail de recherche sur les sociétés anciennes" (Lehoërff 2009,90$)$ et que «les différentes approches particulières à l'archéologie telle qu'on la pratique aujourd'hui peuvent nous faire voir [...] la façon de vivre des gens ordinaires " (Freyne 2006, 81), l'exégèse aurait donc tort de se priver de ces précieuses informations.

L'examen des douze dossiers-test qui suivent vise à permettre de faire le point sur les potentialités et les limites des échanges entre l'encre et la pierre en ce qui concerne la première lettre de Paul aux Corinthiens. Nous les présenterons sous trois rubriques: les mésusages possibles; un bénéfice discuté; un apport non négligeable.

4. Sanders $(2005 \mathrm{a}, 16)$ : «From the mid-1960s to the present, the archaeological study of Corinth has undergone a sustained period of ideological and methodological evolution if not revolution. During this [...] passage, scholars have begun to focus on the human rather than the monumental side of antiquity ». 


\section{Les mésusages possibles}

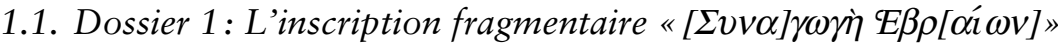

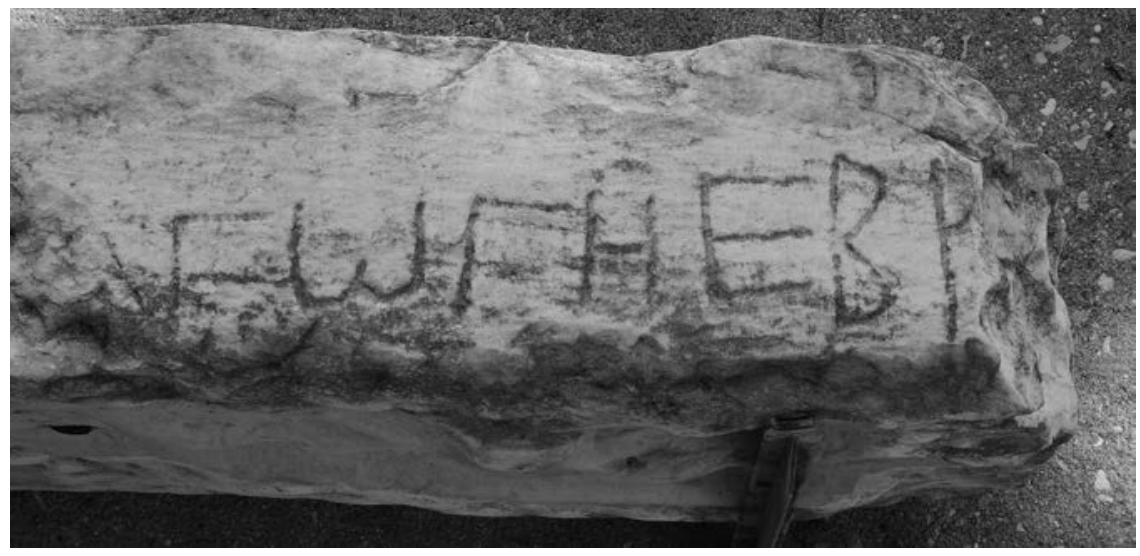

Photo prise par l'auteur

Alors que dans sa quatrième édition de Licht vom Osten, Adolf Deissman n'excluait pas que le bloc de pierre sur lequel étaient gravées maladroitement 7 lettres grecques provenait du linteau de la porte de la synagogue mentionnée en Ac 18,45 , Benjamin D. Meritt optait pour une datation bien plus tardive de cette inscription mise à jour en $1898^{6}$. Qui plus est, il paraît peu vraisemblable qu'une synagogue ait pu se trouver au milieu du premier siècle à l'endroit où ce bloc de pierre a été retrouvé, à savoir sur la route de Lechaion, non loin des Propylées et de la fontaine Pirène (Meritt 1931, 79). On ne saurait donc s'appuyer sur ce seul indice, difficile à dater et qui n'a sans doute pas "été découvert in situ» (Oster 1992, 56), pour confirmer la présence d'une synagogue à Corinthe au temps de Paul ${ }^{7}$.

5. Deissmann (1923, 12-13): «Als äusserste Grenzen der Entstehungszeit der Inschrift seien mit Vorbehalt die Jahre 100 v. Chr. bis 200 n. Chr. zu vermuten. Danach können wir mit der Möglichkeit ernsthaft rechnen, dass es sich um die Türinschrift der Apg 18,4 genannten Synagoge [...] handelt ».

6. Meritt $(1931,79)$ : «The style of lettering indicates that the inscription is considerably later than the time of St. Paul».

7. Oster $(1992,57-58)$ : «We conclude [...] that the archaeological materials cannot fully supply the final answers to the questions posed by the historian and exegete concerning the extent and nature of the Jewish presence in Julio-Claudian Corinth ». 


\subsection{Dossier 2: Les ex-voto enfouis près de l'Asclépieion et la métaphore $d u$ corps utilisée en 1 Co 12,12-27}

On estime à près de $10 \mathrm{~m}^{3}$ l'impressionnante quantité d'ex-voto anatomiques retrouvés dans l'enceinte de l'Asclépieion de Corinthe lors des fouilles consacrées à ce site entre 1929 et 1934 (De Waele 1933, 440). Ils représentent en grandeur nature différentes parties du corps: la tête, les yeux, les oreilles, la langue (?), les cheveux, les bras, les mains, les jambes, les pieds ainsi que les organes génitaux masculins et féminins. Si l'on sait que le sanctuaire dédié à Asclépios est l'un des premiers à avoir été remis en état à l'époque romaine (Bookidis 2005, 159), il s'avère toutefois que les offrandes mises à jour ont été offertes déjà «entre le dernier quart du $\mathrm{V}^{\mathrm{e}}$ siècle et la fin du $\mathrm{IV}^{\mathrm{e}}$ » (Roebuck 1951,113) et qu'elles furent enterrées avec soin lors des travaux d'agrandissement et de réaménagement du sanctuaire à l'époque hellénistique ${ }^{8}$. Quant à d'éventuels ex-voto plus tardifs, qui auraient été visibles à l'Asclépieion de Corinthe du temps de Paul, on n'en a pas trouvé traces au jour d'aujourd'hui. Aussi est-il délicat de suggérer, comme cela a été fait, que de tels objets «ont contribué à former chez Paul l'idée de la communauté chrétienne comme Corps» (Murphy O’Connor 2004, 236) lors de son séjour dans la cité isthmique9. Car cela reviendrait à faire parler un silence archéologique pour expliquer $1 \mathrm{Co}$ 12,12-27 et à projeter sur le siècle de Paul ce qui n'est avéré à Corinthe que pour une période antérieure ${ }^{10}$.

8. De Waele $(1933,440)$ : «The Corinthians planned to built a larger and more regular sanctuary of Asklepios about 338 B.C. [...] They removed in a systematic way the buildings and offerings of the first temple. [...] These offerings were thrown in a heap and afterwards in different drains, fills, wells and manholes. [...] That the seven deposits were contemporaneous is evident".

9. Murphy O’Connor $(2004,238)$ : «Même si Paul connaissait les spéculations de son temps à propos du corps politique, il a fallu nécessairement le déclic d'une expérience comme celle des ex-voto de l'Asclépieion pour expliquer le transfert à l'Église du concept de Corps». Renvoi est fait à Hill (1980, 437-439), lequel indique p. 437: "This brief note suggests that there may be a [...] viable alternative as a possible source [behind Paul's body illustration in 1 Corinthians 12,12-26]. This alternative source is the Asclepian Temple of the city of Corinth. [...] It seems quite reasonable to conjecture that Paul's inspiration for this body illustration may [...] stem from a source directly within the city of Corinth itself ». Dans le même sens, Baslez (2010, 39): «Les fouilles de l'Asclépieion suggèrent que Paul a certainement visité ce sanctuaire guérisseur, dont les ex-voto anatomiques ont pu inspirer certaines de ses métaphores ".

10. Oster $(1992,72)$ : «Votive body parts [...] could have been seen by Paul at any number of locations in the Graeco-Roman world. [...] Devotees of Asclepius in early 


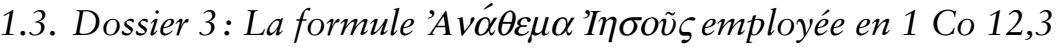

Située en ouverture de la réponse apportée à la question des phénomènes

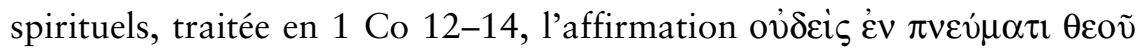

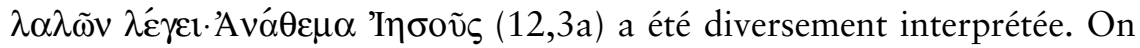

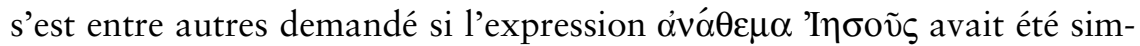
plement forgée pour la circonstance — afin d'être opposée à la confession

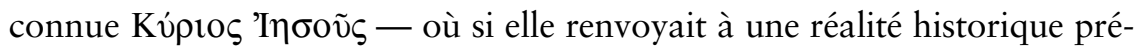
cise $^{11}$.

Dans un ouvrage paru en 2001, Bruce W. Winter a opté pour la seconde solution. Son attention s'est en effet portée sur les tablettes de malédictions employées dans l'Antiquité, dont plusieurs ont été découvertes à Corinthe ou dans ses proches environs ${ }^{12}$, notamment dans le sanctuaire de Déméter et Coré (Bookidis et Stroud 1997, 281-283) ${ }^{13}$. Après avoir relevé l'absence du verbe dans trois des formules déposées en ce lieu et constaté, en particulier sur la base de quelques inscriptions gravées plus tardivement sur des tombes à Corinthe, que les chrétiens ont continué à manier l'art de la malédiction (Winter 2001, 168.173), il propose de traduire $\alpha \dot{v} \alpha \dot{\theta} \theta \mu \alpha$

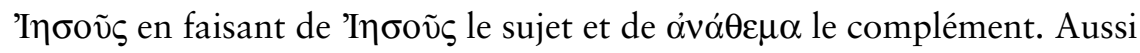
ne lui semble-t-il pas "déraisonnable de rendre 'Avó $\theta \varepsilon \mu \alpha$ 'I "Jesus [grants or gives] a curse" " (Winter 2001, 176); ceci d'autant plus qu'est rappelé au verset précédent le passé païen des destinataires et que la conjonction $\delta$ tó a été employée à l'articulation des v. 2 et 3 . Du point de vue de cet auteur, Paul ne demanderait donc rien d'autre ici à ceux parmi les Corinthiens qui avaient conservé leur ancienne habitude de maudire

imperial Corinth may or may not have regularly used votive items similar to those used centuries earlier. Accordingly, Paul and other Christians may or may not have seen such anatomical votive items ".

11. Pour un aperçu des solutions proposées, voir Thiselton (2000, 918-924).

12. Après avoir dressé l'inventaire de ces tablettes (non encore publiées en 2001) aux p. 164-165, Winter $(2001,165)$ poursuit: «They are but a small part of a large body of extant evidence of the widespread custom of invoking a deity in pagan religion to grant a curse against an adversary in the Graeco-Roman world. [...] Could this evidence, and the practice it represents, cast some light on the enigmatic statement “anathema Jesus” [...] ? » Notons l'avis réservé de Witherington III (1995, 256, n. 9): "Less probable is a link between this verse and the curse tablets found at the Demeter temple».

13. Bookidis et Stroud (1997, 434-435) notent: "The Hellenistic dining unit K-L: 21-22 [...] was refurbished to form a spacious cult building with two or more rooms and an unusual arrangement of supports for what may have been altars that were closely connected with the ceremony of depositing curse tablets "; voir Stroud $(1993,72)$. 
- certes en substituant Jésus aux divinités invoquées jadis - que de renoncer à des pratiques que l'Esprit de Dieu ne saurait cautionner.

Convient-il de privilégier cette ingénieuse solution appuyée sur l'archéologie $^{14}$ ? Ne faut-il pas plutôt en rester à la traduction de ávó $\theta \varepsilon \mu \alpha$ 'Inбoṽ s par "Jésus est anathème ", comme y invite le parallélisme établi

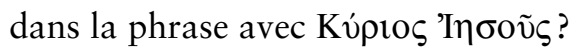

\subsection{Dossier 4: L'inscription [...] erastus pro aedilit[at]e s(ua) p(ecunia)

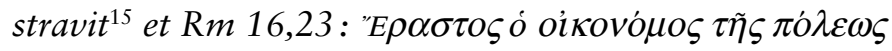

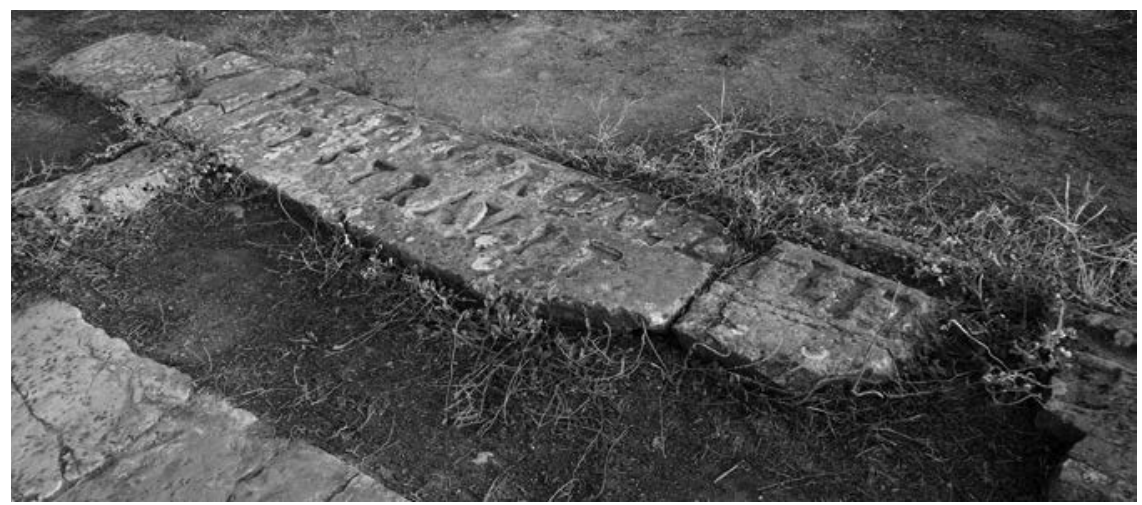

Photo prise par l'auteur

Sous réserve que le personnage dont le nom gravé dans la pierre corinthienne ${ }^{16}$ ait bien eu pour nom Erastus - le nom Eperastus ne pouvant être exclu ${ }^{17}$ - et que les salutations qui se trouvent en $\mathrm{Rm} 16$ aient bien

14. Pour Thiselton $(2006,338)$, «to suggest that some christians claimed to be "spiritual people" at the same time as asking Jesus to impose some "curse" against those who had earned their disfavour [is plausible]».

15. Ce qui est traduit par «[...] Éraste a posé ce pavage à ses frais en remerciement pour son élection à la charge d'édile» par Theissen $(1996,104)$.

16. Voir Kent (1966, 99-100). Trois blocs dégagés en 1928, 1929 et 1947, dont seul celui sur lequel figure le nom Erastus a été découvert in situ, sont actuellement regroupés à l'extemité nord-est du théâtre. Pour l'endroit où ont été trouvés les deux autres, voir Friesen (2010b, 236, n. 20)

17. C'est ce que soutient par exemple Meggitt $(1998,140)$ : "The inscription that we have is not complete. [...] What remains is broken on the $\mathrm{E}$ of Erastus and so, by itself, we have no reason to assume that Erastus is actually a complete word "; contestant l'argument selon lequel on ne peut conjecturer un total que de 7 lettres pour un praeonomen et un nomen avant Erastus, au nom d'une exacte symétrie voir Kent $(1966,100)$ - il conclut, p. 141: «But this is only a possibility». 
été envoyées de Corinthe, il est certes légitime de se demander si l'édile de

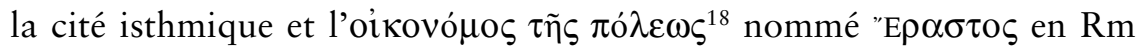
$16,23^{19}$ sont un seul et même individu. Admise par certains ${ }^{20}$, cette identification est remise en question par d'autres, quand elle n'est pas franchement contestée ${ }^{21}$.

Dans l'hypothèse où le pavage financé par l'édile corinthien aurait bien été posé aux environs du milieu du premier siècle de notre ère ${ }^{22}$, «la ques-

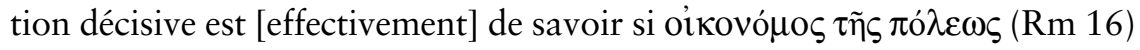
correspond dans les termes et dans les faits à l'édile corinthien» (Theissen 1996, 104). Relevant que «la traduction grecque d'aedilis est d'habitude

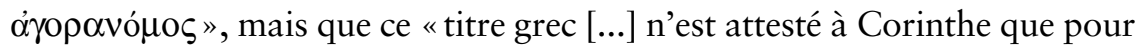
la seconde moitié du deuxième siècle après J.-C. ", Gerd Theissen est d'avis que «les arguments linguistiques ne touchent qu'un aspect du problème " (Theissen 1996, 104-105). Après avoir rappelé que «la plupart de ceux qu'on élisait à une charge communale avaient revêtu auparavant d'autres fonctions » et que "beaucoup d'édiles [avaient auparavant été] questeurs », il suggère que «l'édile Erastus [a] peut-être [d'abord] été questeur» et s'interroge donc: «la fonction de questeur pourrait-elle être l'équivalent de l'oikovó $\mu$ о $\tau \tilde{\eta} \varsigma \pi o ́ \lambda \varepsilon \omega \varsigma$ ? » C’est une "possibilité » qu'il n'écarte pas, tout

18. Pour un dossier épigraphique au sujet de cette expression, voir Cadbury (1931, 47-49).

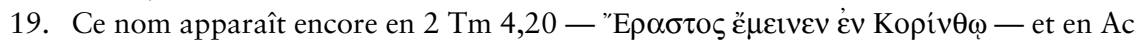

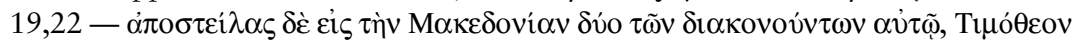

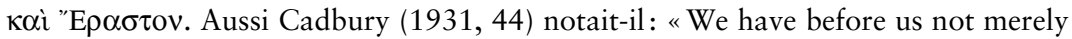
the problem of identification between one Erastus in the New Testament an one on an inscription. The identity of the three Erasti in the New Testament references is not certain and must not be finally assumed ».

20. Pour Baslez (2010,38), elle ne fait pas de doute: «À Corinthe [...], l'épigraphie et la prosopographie permettent d'identifier [...] l'oikonomos Éraste (Rm 16,23) avec le bienfaiteur qui finança le pavage d'une esplanade». Un peu plus nuancés sont les avis de Wiseman $(1980,521)$ : "Erastus, aedile of the city and presumably the friend of the Apostle Paul», et de Koester (2005, 339-340): «Erastus, the city treasurer [...] $(\mathrm{Rm} 16,23)[\ldots]$ is most likely identical with the Erastus of a first-century C.E. inscription found in the pavement of a square near the theater of Corinth".

21. Theissen $(1996,104)$ concède: «Il existe [...] de bonnes raisons de douter de l'identification du chrétien Erastos avec l'édile Erastus ». Très tôt, Cadbury (1931, 58) exprimait ainsi sa réserve: "The identification of the Erastus of the inscription with a New Testament character is improbable if not impossible». Friesen $(2010,231)$ est plus catégorique: "In this chapter I argue that we can disentangle the inked Erastus from the inscribed one. They were two different individuals ».

22. Kent $(1966,99)$ : "The pavement was laid some time near the middle of the first century after Christ». 
en précisant: "Nous ne saurions cependant [la] considérer comme un fait inattaquable». Supposant finalement que «l'année de la rédaction de l'épître aux Romains, Erastos [a] occupé la fonction d'oikovó $\mu$ os $\tau \tilde{\eta} \varsigma$ $\pi$ ó $\lambda \varepsilon \omega \varsigma$ [...], il n’y [aurait] selon [lui] aucun argument décisif [contre une identification avec le chrétien Éraste]» (Theissen 1996, 106-108).

Tout autre est cependant le point de vue de Steven J. Friesen. Relevant non seulement qu'on ne dispose en fait d'aucune preuve archéologique pour dater le pavage de la place des alentours de $50 \mathrm{EC}^{23}$, sa consultation des notes des fouilles l'amène encore à constater que le bloc $\mathrm{A}$ sur lequel est gravé le nom Erastus n'a pas été découvert à l'endroit initial où il avait été posé ${ }^{4}$, mais là où il a été réutilisé ultérieurement pour servir de fondation à un mur ${ }^{25}$. S'appuyant essentiellement sur le fait que des latrines utilisées jusqu'à l'époque d'Hadrien ont été découvertes sous les dalles à l'extrémité est de la place, il lui semble pouvoir avancer que l'édile Éraste a financé les travaux de pose plutôt au cours du second quart du $\mathrm{II}^{\mathrm{e}}$ siècle. Tout en concédant que cette datation n'est que probable, ceci pour deux raisons: on ne peut être certain que le pavage mis à jour est bien celui qui a été sponsorisé par Éraste; une inscription latine de ce type plaide davantage pour une période plus basse. Aussi Friesen n'en reste-t-il pas là pour démontrer que l'édile et l'intendant homonymes sont deux personnes bien distinctes. D'avis surtout qu'on ne peut établir une équivalence entre oikovó $\mu$ os $\tau \tilde{\eta} \varsigma \pi$ ó $\lambda \varepsilon \omega \varsigma$ et aedile, principalement en raison du statut très inférieur de celui qui assure la première fonction par rapport à celui qui exerce la seconde ${ }^{26}$, et refusant le scénario d'une ascension sociale tel que l'a imaginé Theissen, il conclut sans nuance et sur un ton agacé qu'il est

23. Contre Kent $(1966,99)$, Friesen $(2010,237-239)$ déplore un argument circulaire, p. 238 : "The identification of the two Erastus references [...] proved that the plaza came from the 1st century, and the 1st century date of the plaza proved the identification of the two Erastus references ".

24. Friesen $(2010,242)$ : "The inscription in its original position probably served as a step at a point where people entered the plaza ».

25. Friesen $(2010,239)$ : "A second problem [...] is that the Erastus inscription in its present location has no integral connection to the plaza around it. Even a casual examination reveals that Block A was inserted later into the paved area. The block is not aligned with the slabs [...]. The Erastus inscription is not in its original location. It was inserted into this plaza as part of a later foundation ».

26. Friesen $(2010,246-247)$ produit trois inscriptions attestant du rang peu élévé d'un

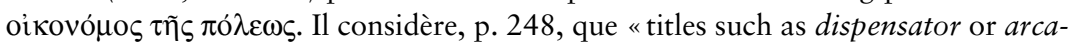
rius would provide a better Latin translation for oikonomos». Il ajoute cependant, p. 249: "Corinth probably had dispensatores and arcarii, but no references to them have survived». 
«impossible d'identifier» (Friesen 2010, 249) l'Éraste épigraphique et l'Éraste de Rm 16 - s'appliquant à démontrer encore que ce dernier n'était pas même un «frère en Christ» (voir Friesen 2010, 249-255).

Quel que soit le point de vue retenu, force est certainement d'admettre que les preuves archéologiques pour conclure à la présence d'un frère de haut statut social du nom d'Éraste dans la communauté corinthienne sont pour le moins extrêmement fragiles. En avons-nous de plus solides pour échafauder des hypothèses plausibles sur les lieux où se réunissaient ceux qui construisaient leur identité en Christ?

\subsection{Dossier 5: La maison, lieu de réunion selon 1 Co 16,19: $\dot{\eta} \kappa \alpha \tau^{\prime}$ oĩ $\kappa o v \alpha \dot{v} \tau \tilde{\omega} v \dot{\varepsilon} \kappa \kappa \lambda \eta \sigma i \alpha$}

Il est vrai que, dans les premiers temps, l'archéologie s'est plus intéressée aux monuments publics qu'à l'habitat et au mode de vie des gens ordinaires ${ }^{27}$. Que pouvons-nous cependant espérer tirer des maigres vestiges de quelques lieux supposés de vie domestique à Corinthe en place autour de 50 de notre ère ${ }^{28}$ ?

Alors qu'il travaillait à l'édition de Corinthe au temps de saint Paul, Jerome Murphy O'Connor (2004) s'est intéressé à celle parmi les quatre maisons dégagées dans la cité isthmique ${ }^{29}$ qui existait du temps de Paul et

27. En ce qui concerne Corinthe en particulier, Horrell $(2004,360)$ relève: «Unfortunately, despite the major and long-established excavations at Corinth, very little is known about the character of many of the residential areas of Roman Corinth, since excavations have been largely concentrated around the forum area, on the sanctuaries of Demeter and Kore and of Asclepius, on a small number of selected villas, and on other significant structures in and outside the city ».

28. C'est à cette question que veut répondre l'enquête de Schowalter (2010, 327-341). Il prévient d'emblée, p. 328: «We [...] do not have a sufficient range of evidence to talk about Corinthian domestic space in a comprehensive way. [...] The sample size of domestic space in 1st century is simply to meager to generalize about where and how the majority of the population would have lived".

29. Wiseman (1980, 528) dresse le bilan suivant: "Few of the private residences of Roman Corinth have been excavated. A house with a peristyle courtyard, the latter paved with marble, seems to have been attached to the northwest corner of the temenos of Temple E, but it is unclear whether or not the dwelling was associated with the cult of the temple. A villa with mosaics of exceptionally high quality was excavated in 1962-1964 about $750 \mathrm{~m}$. to the west of Temple E [...]. The mosaics have been dated to the late 1st century after Christ on stylistic grounds and pottery of ca. A.D. 50-75 found below the mosaic provide an archaeological terminus post quem. The villa, however, was already in existence when the mosaics were added. Another sumptuous villa of the $2^{\text {nd }}$ century has been excavated in the vicinity of the old Sicyo- 
que l'on nomme la "villa d'Anaploga ". Fouillée entre 1962 et 1964, elle est située à environ 750 mètres au sud-ouest du Forum. Même si la très belle mosaïque découverte dans une grande pièce date de la fin du $\mathrm{I}^{\mathrm{er}}$ siècle ÈC, on sait que le bâtiment en soi est plus ancien (voir Grobel Miller 1972). D’avis «que les réunions qui dépassaient le cercle très intime des amis de la famille se tenaient exclusivement dans la partie publique de la maison ", Murphy O'Connor observe alors que ce qu'il tient pour le triclinum «mesure 5,5 [...] par 7,5 mètres " et que "l'atrium mesure 5 [mètres] sur 6 ", mesures qui, comme l'indique la comparaison avec d'autres données, sont les "dimensions [...] typiques » à l'époque (Murphy O’Connor 2004, 222). Aussi estime-t-il qu'une maison individuelle de ce genre pouvait accueillir en moyenne 9 personnes dans le triclinum et entre 30 et 40 personnes dans l'atrium (Murphy O'Connor 2004, 226). Cette hypothèse, dont on ne saurait nier l'intérêt, n'est cependant pas sans poser question. On ne peut en effet dire avec certitude ce à quoi servait à l'origine la pièce identifiée en tant que triclinum avant d'être agrandie et décorée ${ }^{30}$. Plus fondamentalement encore, on se demande même si cette structure était à l'origine réellement une maison d'habitation ${ }^{31}$.

C’est pourquoi David G. Horrell a préféré porter son attention sur les bâtiments 1 et 3 qui bordent le bout de la rue longeant le côté est du théâtre, deux constructions au plan relativement similaire ${ }^{32}$ et dont la pièce du rez-de-chaussée située au nord était équipée de fours ${ }^{33}$. Il est possible qu'il

nian Gate. A still later house, perhaps ca. A.D. 200, was built against the east wall of the South Basilica along the road to Cenchreae».

30. Horrell $(2004,356)$ : «So far as the archeological evidence is concerned, we cannot with any confidence presume that the mosaic room at Anaploga functioned as a triclinium, and certainly not in Paul's time».

31. Schowalter $(2010,331)$ : "Partially excavated in 1962-64, the result from the [Anaploga] villa were never published in a systematic way. [...] Without conducting further research, it is impossible to be certain, but there is a definite possibility that the site may not have been a villa at all in the mid 1st century CE»; pour Robinson $(1965,291)$, «this may have been a merchants' club».

32. Williams II $(2005,227)$ : «Buildings 1 and 3 appear to have been constructed as a single architectural project, if one is to judge from their homogeneous western facade and their similitary in plan".

33. Voir Williams II et Zervos (1986). Williams II et Zervos $(1988,122)$ avancent: "Evidence for the initial construction date of Building 1 is meager, but, according to the numismatic evidence, Building 3 to its south could have been constructed at any time after A.D. 12/3-15/6. If one says rather tentatively that both Building 1 and Building 3 were constructed after A.D 12-15, one can say more positively that they existed before the earthquake of A.D. 77 ». 
s'agissait de tabernae ou de popinae ${ }^{34}$. Étaient-ce des maisons à deux étages? Les rapports archéologiques l'ont jusqu'à présent laissé supposer ${ }^{35}$. Si tel devait être effectivement le cas, nous aurions alors selon Horrell un autre exemple de bâtiment domestique ${ }^{36}$ susceptible d'accueillir à l'étage un groupe $^{37}$, en l'occurrence une maison beaucoup plus modeste qu'une villa romaine et située au centre-ville ${ }^{38}$. Et Horrell de conclure que le scénario d'une rencontre de frères en Christ du temps de Paul en un tel lieu, même s'il relève de ce qu'il appelle l' «imagination disciplinée » (Horrell 2004, 367), est sans doute moins spéculatif que celui proposé par Murphy O’Connor sur la base des fouilles menées dans la supposée villa d'Anaploga ${ }^{39}$.

34. Horrell $(2004,364)$ : «One possibility is that they were tabernae or popinae [...]. They most likely served as some kind of butchery kitchens, preparing and selling cooked meats to visitors to the theatre and other residents in the neighbourhood»; Williams II $(2005,223)$ : «Buildings 1 and 3 at the foot of the street appear to have been erected specifically to cater food to theatergoers attending performances. Not only do the north rooms of both buildings contain large domed ovens, but the number of bones found in Building 3, especially in its south room, indicate that large amounts of meat were served there».

35. Williams II et Zervos $(1986,148)$ : «It therefore seems best [...] that one should consider Building 3 and, most likeky, Building 1 as two storied, possibly three storied ». Schowalter (2010, 333-334) annonce pourtant: "Charles Williams reported that the final publication of the East Theater Street buildings would not include evidence for a second story".

36. Horrell $(2004,366)$ : «The considerable variety of possible types of domestic space - from country villas to peasant homes, smart town apartments to rooms behind or over a shop, not to mention the more ramshackle and temporary dwelling of the destitute - means that we should be wary of labelling any specific form as "typical" ".

37. Horrell $(2004,367-368)$ : «In a fairly large upper room, or rooms, equipped perhaps with some tables and benches, it would be by no means be impossible to cram in 50 or so people, though this would probably be pretty crowded".

38. Horrell $(2004,367)$ : "The discoveries of East Theater Street [...] enable us, using our "disciplined imagination", to go some way towards picturing one kind of domestic space in which Christian could have met, the kind of space that might well have been occupied by small traders and business folk [...]. Such people were not from the lowest social strata; they may have [...] been able to afford some "luxuries", as the wall-paintings in building 3 indicate».

39. Horrell (2004, 368-369): «Picturing the first Christians in Corinth meeting in an upper-storey room in East Theater Street is, of course, entirely imaginative, though no more so (and probably a good deal less so) than imagining them meeting in the villa at Anaploga. [...] The East Theater Street scenario [...] represents one form of urban accommodation that existed during the time of Paul's visits to Corinth, a type likely to have been occupied by non-elite, though not the most impoverished, urban residents" . 
On admettra cependant avec Daniel N. Schowalter que nous ne disposons pas actuellement de supports archéologiques suffisamment sûrs pour répondre avec un degré de vraisemblance acceptable à la question des cadres dans lesquels les frères et les sœurs en Christ se sont retrouvés à Corinthe du temps de Paul ${ }^{40}$.

\section{Un bénéfice discuté}

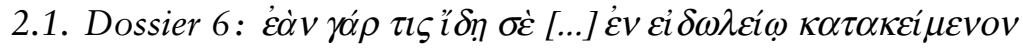
(1 Co 8,10): les salles à manger attenantes à l'Asclépieion étaient-elles ouvertes au public?

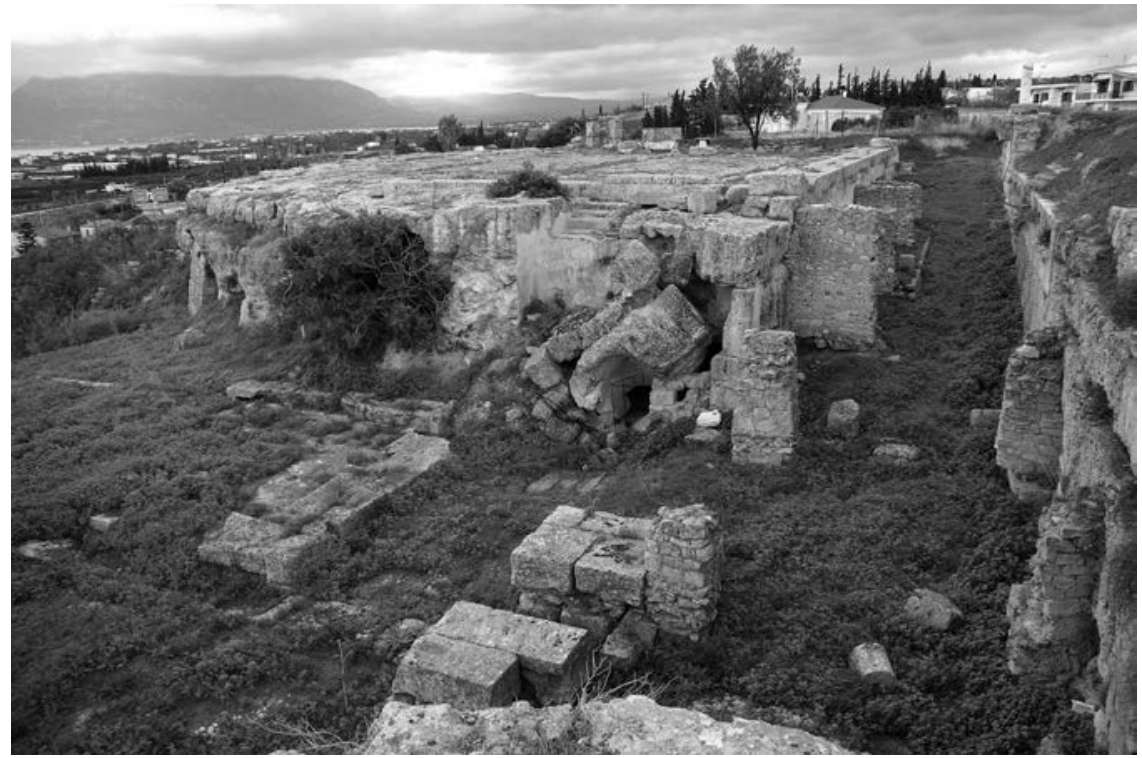

Photo prise par l'auteur

Parmi les lieux supposés où «celui qui a la connaissance » pouvait être vu attablé dans un temple d'idole, il y a les trois salles à manger attenantes à

40. Schowalter $(2010,335-336)$ : «Is it time to admit that our ability to distinguish potential ekklesia space in 1st century Corinth is compromised for the immediate future by a lack of specific archaeological evidence "; l'auteur ajoute, p. 341: «It may very well be that finding ways of talking about the 1 st century assemblies of believers without attempting to tie them to particular locations may provide a foundation for advancing the subject in the future». 
l'Asclépieion. Elles sont situées du côté est de la cour aménagée en contrebas du temple ${ }^{41}$, un espace qui a été assimilé dans un premier temps à la fameuse fontaine appelée "Lerna" par Pausanias ${ }^{42}$ — à cause de la présence d'une source et de réservoirs taillés dans la roche sur le côté sud ${ }^{43}$. Mais depuis que James Wiseman a dégagé en 1967, dans l'aire du gymnase à quelques $200 \mathrm{~m}$ à l'ouest de l'Asclépieion, une autre fontaine — baptisée tout d'abord «la fontaine des lampes» (voir Wiseman 1970) —, tout indique que c'est bien cette dernière infrastructure qu'il convient d'identi-

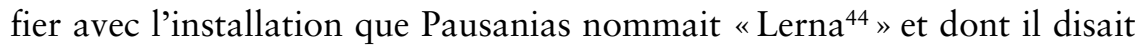
qu' « elle est bordée de colonnades pourvues de bancs pour délasser au frais les visiteurs, durant la saison d'été ». Pour autant, faut-il en déduire qu'au contraire de «Lerna ", la cour inférieure accolée à l'Asclépieion «faisait partie intégrante du sanctuaire ${ }^{45}$ » ? Peut-on exclure qu'elle servait (elle aussi)

41. Roebuck (1951, 54-55): "The rooms seem to have been continued in use throughout the Roman period".

42. Pausanias 2,4,5: "Par-delà le théâtre se dresse le sanctuaire de Zeux capitolin, comme on dit à Rome [...]. Dans le voisinage du théâtre se trouve l'ancien gymnase et la source "Lerna". Elle est bordée de colonnades pourvues de bancs pour délasser au frais les visiteurs, durant la saison d'été. Touchant à ce gymnase se dressent le temple de Zeus et celui d'Asclépios. Les statues d'Asclépios et d'Hygie sont de marbre blanc, celle de Zeus en bronze» (traduction Roux 1958, 46).

43. De Waele $(1935,353-354)$ : «Although we possess no literary or epigraphic evidence to confirm our identification of this complex with the "so-called fountain of Lerna", as Pausanias says, it is almost beyound doubt that the remains of constructions around the large square really belong to Lerna »; Roebuck $(1951,2)$ observait cependant: "It is to be noted, however, that Pausanias' account does not couple the Asklepieion and Lerna so closely as the remains might seem to indicate».

44. Wiseman $(1980,511)$ : «The complex is more likely to be Pausanias' Fountain of Lerna than the fountain to the east that is usually so identified »; à la p. 112, il avance les raisons qui l'ont poussé à identifier la «fontaine des lampes » avec «Lerna »; Williams II et Zervos $(1984,103)$ : «I, personally, prefer the identification of a monument around the Fountain of the Lamps as the Lerna mentioned by Pausanias, leaving the lower court west of the Asklepieion published originally as the Lerna, to be an unnamed lower court of the Asklepieion itself»; Fotopoulos $(2006,41)$ : «The columns standing around the Fountain of the Lamps, its underground bathing room and outdoor pool with their large kathedrai fit Pausanias' description of Lerna precisely as a spring with columns around it having seats offering refreshment to those who enter in summer time».

45. C'est l'avis de Baslez (2010, 39): "L'édifice à salles à manger, loin de fonctionner comme un "club" pour des parties de campagne, faisait partie intégrante du sanctuaire et était considéré comme un lieu sacré ». Dans ce sens également, Fotopoulos (2006, 47), qui parle de «structural and functional relationship of the Asklepieion with it spring and dining rooms as a unifite site». Aussi conclut-il, p. 48: "Clearly 
d'espace public ${ }^{46}$, offrant aux habitants des quartiers alentours une aire de détente et des installations pour y organiser un repas de fête ${ }^{47}$ ? Pour notre propos, cette question revient à demander quels étaient les utilisateurs des trois salles à manger équipées chacune de onze banquettes. Les seuls patients du sanctuaire, consommant de la nourriture sacrifiée à Asclépios, ou des convives variés, réunis en cet endroit pour un motif autre que la dévotion rendue à Asclépios ${ }^{48}$ ?

Dans l'impossibilité de trancher avec une entière certitude, il nous semble préférable de laisser la question ouverte. Aussi ne peut-on affirmer que les premiers lecteurs d'1 Co - du moins ceux à la conscience faible - tenaient ipso facto les nourritures servies dans ces trois salles pour des mets sacrifiés ${ }^{49}$.

the Corinthian Christians would understand the meals served in the Corinthian Asklepieion to consist of sacrificial food. Thus, eating in these dinning rooms would meet Paul's description of "reclining in an idol's temple" $(8,10)$ ».

46. La question a été soulevée par Roebuck $(1951,24)$ : "Should we [...] regard the whole area as an Asklepieion, divided into a precinct and a resort for the patients, or was [the square] regarded also as a public fountain which might have served that quarter of the city? " Et l'auteur de répondre, p. 25: "It seems probable that, in view of the unusually large amount of water avaible [...], it was intended to be a public supply, but, since it was closely linked with the Asklepieion, that patients also made constant use of its facilities. [...] In the Roman period it seems probable that this public character [...] was further emphasized. [...] It is probable that [the square] was regarded in some degree as the secular part of the establishment ".

47. Murphy O'Connor (2004, 233-234): «Même sans la colonnade, l'espace ouvert, en avant des salles de banquet, constituait une parfaite petite piazza [...]. Selon toute probabilité elle devait être fréquentée non seulement par les patients de l'Asclépieion, mais encore par des visiteurs occasionnels en quête d'un moment de répit loin du bruit et de l'agitation de la cité».

48. La condamnation de la rampe d'accès à la cour inférieure longeant le sanctuaire côté sud au milieu du premier siècle de notre ère n'interfère guère dans ce débat, dans la mesure où il faut supposer l'existence de deux autres accès au moins. C'est ce qu'indique Roebuck $(1951,91)$ : «Probably, the ramp from the east along the top of the city wall was maintained throughout the Roman period [...]. We have also restored a small doorway in the northwest corner of the west colonnade of the square. Entrance from this direction would have been desirable at all periods ».

49. Oster $(1992,66)$ : «It must be remembered that temple dining halls were also used for ceremonies other than the official cultus of the deity". 


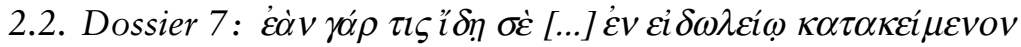 (1 Co 8,10): qui mangeait dans le sanctuaire de Déméter et Coré à l'époque de Paul?}

Parmi les lieux potentiels auxquels renvoie l'éventualité d'être vu en train de manger dans un temple païen, on a également envisagé le sanctuaire de Déméter et Coré (voir Oster 1992, 64-67). Les fouilles ont révélé que ce site, dont la première occupation remonte $\mathrm{au} \mathrm{VIII}^{\mathrm{e}}$ siècle avant notre ère (Bookidis 2005, 147), a été réutilisé non longtemps après la refondation romaine de Corinthe ${ }^{50}$ - sans que l'on sache vraiment dans quel état il se trouvait à ce moment-là (Bookidis et Stroud 1997, 434). S'il est avéré que des repas rituels pris en petits groupes dans les nombreuses salles à manger jouaient un rôle important à l'époque grecque (Stroud 1993, 68), rien n'assure toutefois que cette pratique se soit perpétrée sous cette même forme à l'époque romaine ${ }^{51}$. Le flou qui entoure l'utilisation du site durant la première moitié du $\mathrm{I}^{\mathrm{er}}$ siècle de notre ère ${ }^{52}$ ne permet en effet que d'avancer l'hypothèse de repas cuisinés en plein air pour des convives installés à l'ombre d'une tente ${ }^{53}$.

On mangeait donc dans l'enceinte de ce sanctuaire du temps de Paul. Mais il n'est pas possible de préciser qui mangeait. La possibilité que des membres de la jeune église aient été invités à partager un repas en un tel lieu, sans être entièrement exclue, reste au final très hypothétique.

50. Stroud $(1993,67)$ : «We do not know how soon after the foundation of the Roman colony in 44 B.C. construction was resumed in the Sanctuary of Demeter. Pottery, lamps, and other small finds are not very numerous until the middle of the 1 st $\mathrm{c}$. A.D., but a high proportion of coins from the reigns of Augustus and Tiberius suggests that the Sanctuary was revived not too long after the refounding of Corinth ".

51. Bookidis et Stroud $(1997,434)$ : «The Hellenistic dining unit K-L: 21-22 survived in good enough condition to be reused in part during the early phases of the Roman shrine. [...] Communal meals of the old type seem no longer to have formed part of the ritual in this building. Nor is there evidence elsewhere in the Roman Sanctuary to indicate a continuation of this practice ".

52. Bookidis et Stroud $(1997,273)$ : "It is difficult to reconstruct the earliest stages of Roman occupation [...] of the Sanctuary as a whole. [...] A small amount of Early Roman pottery - some clearly ritualistic — was recovered from various parts of the site [...]. These pieces argue for a Roman presence on the site already in the first half of the 1 st century after Christ".

53. Bookidis et Stroud $(1997,273)$ : «It may be that this earliest worship was conducted in the open air»; Wiseman, $(1980,509)$ : «The quantities of Roman cooking ware in the area indicates that meals, perhaps prepared outdoors and served in tents, continued to be major elements of the ritual». 


\subsection{Dossier 8: Les jeux isthmiques et les métaphores sportives employées en 1 Co 9,24-27}

Paul fait-il spécialement allusion aux jeux isthmiques lorsqu'il évoque en 1 Co 9,24-27 l'ascèse rigoureuse que s'imposent les athlètes? S'est-il luimême rendu à cette manifestation biennale lors de son séjour fondateur à Corinthe?

L'utilisation rhétorique des images de la course et du pugilat dans le court développement qui clôt 1 Co 9 ne présuppose aucunement que l'apôtre ait assisté à de telles compétitions, que ce soit dans la cité isthmique ou ailleurs. On en veut pour preuve que les métaphores sportives étaient couramment utilisées dans l'Antiquité, tant dans la tradition grecque que dans le judaïsme hellénistique (Brändl 2006). Certes, le fait que la ville de Corinthe organisait tous les deux ans ces jeux panhelléniques n'est peutêtre pas étranger au choix de ces images, leur arrière-plan local ne leur donnant que davantage de force.

Mais, demandera-t-on surtout, le fait même que Corinthe soit une ville de jeux n'a-t-il pas pesé dans la décision de Paul de s'y rendre? Sans qu'on puisse l'affirmer avec certitude ${ }^{54}$, on admettra cependant que cette manifestation offrait un double atout pour lui. La demande en tentes, en auvents et autres réalisations faites de toile et de cuir ne générait-elle pas du travail pour l'artisan qu'il était ${ }^{55}$ ? Et les foules réunies à l'occasion de ces jeux ne constituaient-elles pas un auditoire rêvé pour qui annonçait l'Évangile ${ }^{56}$ ? Nous laisserons à Oscar Broneer (1962, 20-30) la responsabilité de la fiction qui imagine Paul et ses collaborateurs se rendant aux jeux isthmiques en l'an 51 ÈC. Plus discutée est aujourd'hui la question du lieu où ils se sont déroulés cette année-là, alors même que Paul se trouvait vraisemblablement à Corinthe. En effet, l'hypothèse de jeux définitivement rapatriés

54. Broneer $(1962,2)$ : «Can it be that the Isthmian Games influenced him in his choice of Corinth [...] ? The answer is a qualified yes ».

55. Broneer $(1962,5)$ : «Corinth doubtless offered better business opportunities to a man in his trade than did most Greek cities because of his wealth and business activities and, in particular, because of the Isthmian Games. At such occasions large number of tents would be needed to provide shelter for the crowds of visitors »; Brändl (2006, 240-241) imagine même qu'Éraste a pu commander à Paul des tentes et des auvents pour les jeux isthmiques.

56. Broneer $(1962,5)$ : «We may reasonably assume that Paul made use of the opportunity to deliver his message to the many visitors at Isthmia "; voir, avec davantage de réserves, Brändl (2006, 242-243). 
au sanctuaire de Poséidon au tournant de notre ère ${ }^{57}$ a été remise en cause par Elizabeth R. Gebhard ${ }^{58}$. Suite aux apports de nouvelles fouilles réalisées sur le site du sanctuaire de Poséidon en 1989, elle estime pour sa part que c'est uniquement entre 50 et 60 ÈC $^{59}$ que les rénovations nécessaires pour pouvoir réutiliser l'ancien site furent achevées. Ce qui signifierait que la localisation des jeux de 51 reste incertaine.

\subsection{Dossier 9: Les hôtes prenaient-ils occasion des repas pour rallier leurs invités à leur appartenance préférentielle? Une lecture croisée d'1 Co 1,11-12 et 11,17-34}

Chaque personne construisant son identité en Christ à Corinthe revendiquait-elle un attachement privilégié à Paul, à Apollos ou à Céphas, comme voudrait le laisser entendre la formule stylisée employée en 1 Co 1,1260

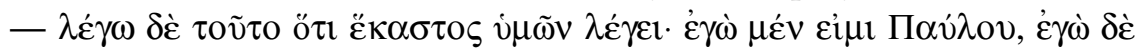
'A $\pi \mathrm{o} \lambda \lambda \tilde{\omega}, \dot{\varepsilon} \gamma \hat{\omega} \delta \dot{\varepsilon} \mathrm{K} \eta \phi \tilde{\alpha}, \dot{\varepsilon} \gamma \omega \grave{~} \delta \dot{\varepsilon} \mathrm{X} \rho \iota \sigma \tau 0 \tilde{v}$ ? Un autre scénario a été envisagé.

Si on admet avec Jerome Murphy O'Connor ${ }^{61}$ qu'il faut distinguer entre l'église entière - $\dot{\eta} \dot{\varepsilon} \kappa \kappa \lambda \eta \sigma i \alpha$ ö $\lambda \eta$ (1 Co 14,23) — et l'église [qui est]

57. Wiseman $(1980,531-532)$ : «During the first 40 years or so of the colony at Corinth there seems to have been little activity at the Isthmian Sanctuary; priority for construction obviously lay within the refounded city itself. Doubtless there was some repair and general tidying within the temenos of Poseidon and the stadium in preparation for the return of the games from Sicyon, but the first major building program was probably inaugurated by L. Castrius Regulus, agonothes of the games in 6 B.C. or 2 B.C., when they were held for the first time at the Isthmia since the refounding of the city".

58. Gebhard $(1993,78)$ pose deux questions distinctes: «When after the foundation of the Colonia Laus Julia Corinthiensis did the Isthmian Games return to Corinthian control ? [...] When did the festival return to its traditional home at the Isthmian Sanctuary of Poseidon?"

59. Gebhard $(1993,88)$ : "The absence of substantial archaeological remains around the temenos of Poseidon and the theater in the Isthmian sanctuary makes it likeky that the actual celebration of the games remained largely in Corinth until the principate of Nero"; l'auteur ajoute, p. 94: "The festival did not come to be held regulary at the Isthmian sanctuary until A.D. 50-60».

60. On n'oubliera pas que la présentation de la communauté corinthienne en 1 Co 1,10-4,21 reflète la lecture paulinienne des informations apportées par les gens de Chloé.

61. Murphy O’Connor $(2004,227)$ : «Il semblerait [...] qu'une réunion de "toute l'église" (Rm 16,23; 1 Co 14,23) était chose exceptionnelle [...]. L'adjectif "toute" est superflu si les chrétiens de Corinthe ne se réunissaient qu'en un seul groupe: il faut donc comprendre qu'il implique l'existence d'autres groupes. Cette remarque 


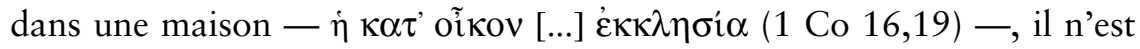
que légitime de se demander si les divisions dont il est question en 1 Co 1-4 n'ont pas partie liée avec le fait que les différents sous-groupes de la communauté corinthienne "se réunissaient habituellement séparément ${ }^{62}$ ". Se pourrait-il que ce soient les différents hôtes qui, forts de leur statut, aient cherché à imposer à leurs convives leur préférence pour Paul, Apollos ou Céphas? James C. Walters (2010) est enclin à le penser ${ }^{63}$. Il fonde cette hypothèse sur le paragraphe 132 de la charte coloniale d'Urso - la Lex Coloniae Genetivae Iuliae — gravé dans le bronze de tablettes découvertes en $1870-1871^{64}$ et qui trace une claire limite entre l'invitation désintéressée à un repas et la pêche aux voix ${ }^{65}$. Il s'appuie donc sur cette dénonciation de l'influence exercée par certaines personnes en vue sur l'électorat pour supposer qu'à Corinthe également, certains hôtes profitaient de l'accueil qu'ils offraient dans leurs maisons, notamment à l'occasion du repas du Seigneur, pour inciter leurs convives à prendre position plutôt pour Apollos ou Céphas ${ }^{66}$.

suggère que les expressions: “toute l'église” et "l'église chez X” (Rm 16,5; 1 Co 16,19; Col 4,15; Phm 2) ne sont pas équivalentes, mais bel et bien contrastées. [...] "L'église chez X" serait donc un sous-groupe de la communauté".

62. Murphy O'Connor $(2004,228)$ : «Ces sous-groupes [...] devaient [...] tendre à créer des divisions à l'intérieur de la communauté urbaine plus large. Il paraît probable que les différents groupes mentionnés par Paul en 1 Co 1,12 se réunissaient habituellement séparément. Cet isolement relatif signifiait que chaque groupe avait une chance d'élaborer sa propre théologie [...]. La difficulté de réunir régulièrement toute l’Église ensemble explique dans une large mesure les divisions théologiques à l'intérieur de la communauté de Corinthe».

63. Walters $(2010,343)$ introduit ainsi sa contribution: «In this essay I will argue that Paul's rebuke of the Corinthians for their meal practice in the setting of the Lord's Supper and his corrective instructions (1 Co 11,17-31) are best understood as an attempt to limit the power that Paul's rivals could exert through meals. This thesis depends on recognizing the utility of meals as contexts within which hosts were able to wield considerable influence, the crisis of leadership Paul faced at Corinth, and the potential effects of Paul's instructions on those hosting meals in the Corinthian ekklesia».

64. Ce texte législatif est contemporain de la fondation de la Colonia Laus Iulia Corinthiensis dont la charte n'a malheureusement pas été retrouvée.

65. Walters $(2010,344-345)$ : «What this law seeks to make clear is the boundary between hosting an innocent meal - or giving an innocent gift - and electoral bribery. Most importantly, the law provides the ground for an interested party to bring legal action against a rival who may have used meals unlawfully — or other favors - to garner votes ".

66. Walters $(2010,363)$ : «Paul's regulations for the community meal in Corinth sought to accomplish something quite similar to what the colonial charter from Urso sought 
Ce parallèle établi entre deux contextes bien différents est certes osé, mais il informe utilement sur l'usage intéressé qu'on pouvait faire de l'invitation à un repas. Malgré son intérêt, cette piste ne résout cependant pas à elle seule la question de l'interprétation d'1 Co 11,17-34.

\section{Un apport non négligeable}

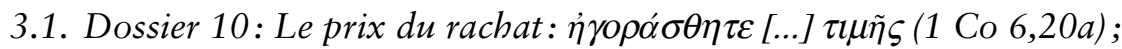 $\tau \imath \mu \tilde{\eta} \varsigma \dot{\eta} \gamma о \rho \alpha ́ \sigma \theta \eta \tau \varepsilon$ (1 Co 7,23a) et les inscriptions de Delphes}

En deux occasions, Paul emploie la métaphore de l'«achat pour un prix ».

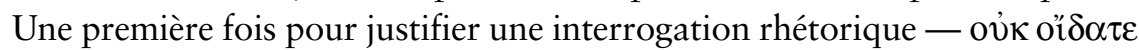

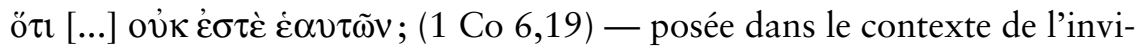
tation à fuir la débauche $(1$ Co 6,18) et à glorifier Dieu par son corps (1 Co $6,20 \mathrm{~b})$. Puis dans le cadre d'une exhortation adressée à chacun de demeurer dans la condition qui était la sienne lors de son appel (1 Co 7,20.27) et de ne pas céder aux logiques et aux aspirations proprement humaines (1 Co 7,23b).

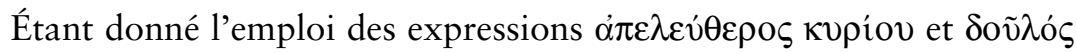

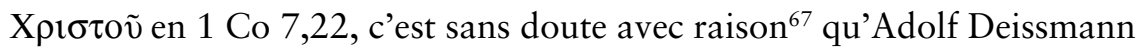
(1923, 271-275) propose de mettre l'image de l'«achat pour un prix » en lien avec «l'affranchissement des esclaves par forme de vente à une divinité » (voir Foucart 1867). Cette pratique de vente fictive, par laquelle l'esclave était acheté par le dieu, est en effet attestée par de nombreuses inscriptions, gravées sur le mur de soutien polygonal de l'esplanade du temple d'Apollon pythien à Delphes au commencement du $\mathrm{II}^{\mathrm{e}}$ siècle avant notre ère.

La formule la plus simple [d'un tel acte] et à laquelle peuvent se ramener toutes les autres [est]: "Cléon, fils de Cléoxénos, a vendu à Apollon Pythien un corps mâle, qui a nom Istiaeos, Syrien, pour le prix [ $\tau \mu \tilde{\alpha} \varsigma]$ de quatre mines, à condition qu'Istiaeos soit libre et que nul ne puisse mettre la main sur lui pendant toute sa vie". [...] Cet acte n'était pas, à proprement parler, un affranchissement; l'affranchissement en était le résultat, mais indirecte-

to accomplish : individual candidates - or their supporters - would not be able to use their status as meal hosts to tilt "voters" toward their aspirations of leadership in the colony".

67. Ceci malgré les réserves avancées par Thiselton (2006, 335). 
ment; [...] c'était un contrat de vente entre le dieu et le maître (Foucart 1867, 2.3.23) ${ }^{68}$.

Certes, on ne poussera pas la comparaison au-delà du raisonnable.

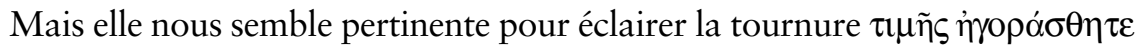
utilisée à deux reprises en 1 Co par Paul.

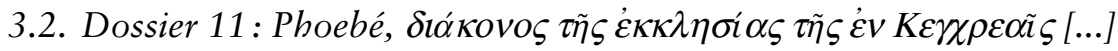

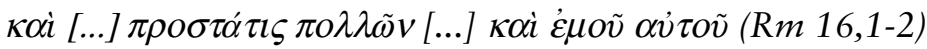

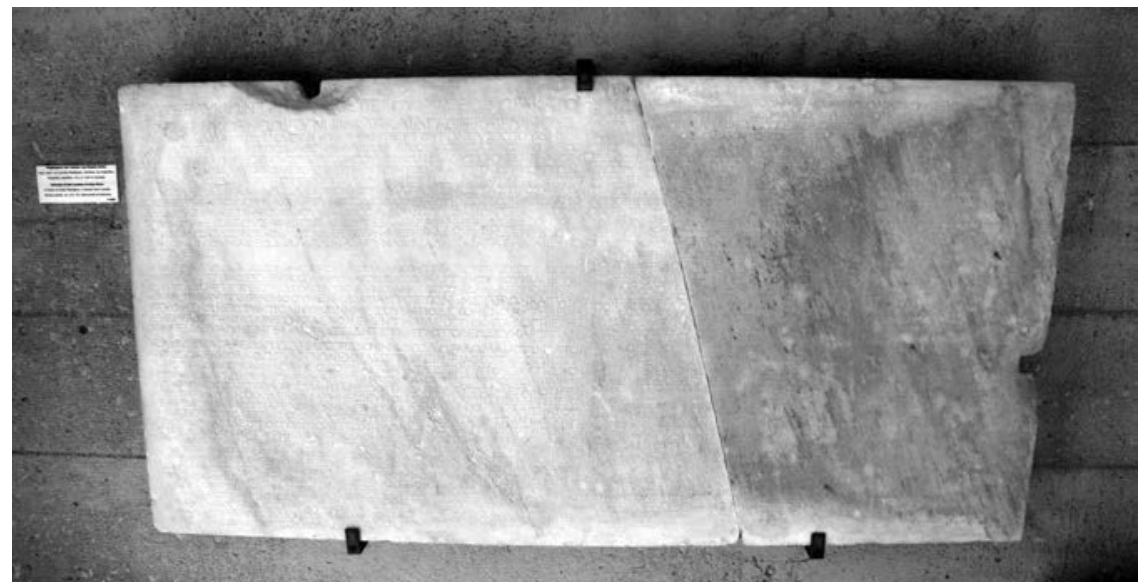

Photo prise par l'auteur

Les seules informations directes dont nous disposons au sujet de Phoebé ${ }^{69}$ sont celles fournies par la recommandation qui ouvre l'actuel dernier chapitre de la lettre de Paul aux Romains, unique endroit où il est question de cette sœur - $\dot{\eta} \dot{\alpha} \delta \varepsilon \lambda \phi \grave{\eta} \dot{\eta} \mu \tilde{\omega} \nu$ — dans le Nouveau Testament. Paul donne deux précisions supplémentaires à son sujet, relativement ambigües tou-

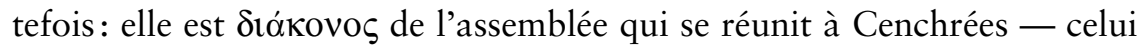

68. Foucart $(1867,43-45)$ précise, p. 43-45: «Ce genre d'affranchissement n'est pas particulier à Apollon; on a retrouvé des actes analogues dans les temples d'Esculape à Stiris et à Élatée; de Sérapis à Chéronée, à Tithorée, à Coronée; de Baccus à Naupacte, de Minerve Poliade à Daulis, et même de Vénus Syrienne à Phiscis [...]. C'était la divinité principale de chaque ville dont le temple servait à ces affranchissements. [...] Ce fut un usage local, [...], mais qui ne s'étendit guère au-delà de Delphes et des contrées voisines».

69. Prigent $(2002,180)$ remarque : «Le nom, d'origine mythologique, ne peut être celui d'une juive. Phoebé est une païenne convertie». 
des deux ports de Corinthe situé à l'est, sur le Golfe saronique ${ }^{70}$ — et $\pi \rho o \sigma \tau \alpha^{\prime} \tau \varsigma^{71}$ de nombreuses personnes, y compris de l'apôtre ${ }^{72}$.

Quel que soit le sens exact qu'il convient de donner ici au titre de

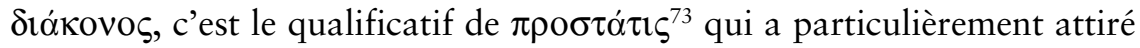
l'attention depuis la découverte d'une tombe, en 1954, au sud-est de Corinthe, dont «l'entrée était fermée par une grande plaque de marbre inscrite [provenant] d'un monument plus ancien» (Pallas et al. 1959, $496)^{74}$. Or, sur cette stèle où sont gravés - sur deux colonnes comptant un total de 85 lignes - cinq décrets de Lycie honorant une certaine Junia Théodora, citoyenne romaine (1. 13.22.63.67.72) ${ }^{75}$ et habitante de Corinthe (1. 1-2.22-23.45.47-48.63.67 ${ }^{76}$, il se trouve qu'il est fait usage à la ligne 77 du terme $\pi \rho 0 \sigma \tau \alpha \sigma i \alpha$, un mot apparenté à $\pi \rho 0 \sigma \tau \alpha \dot{\tau} \tau \varsigma$. Aussi s'est-on à juste titre autorisé à rapprocher Phoebé de Junia Théodora, afin de déduire du portrait de la seconde quelques traits, certes hypothétiques, de la première.

70. Rife (2010, 396-397): "With the Caesarian foundation and the subsequent revival of Corinthian commerce, the eastern port was slowly reborn. [...] Thus, while the harbor surely received ships, traders, and travelers from the earliest days of the Corinthian colony, it seems that the town did not flourish until the early the middle 1st century. [...] But it was never a city in the sense of an autonomous municipality ».

71. F et $\mathrm{G}$ remplacent l'hapax néotestamentaire $\pi \rho 0 \sigma \tau \alpha \dot{\tau} \iota \varsigma$ par $\pi \alpha \rho \alpha \sigma \tau \alpha \dot{\sigma} \sigma \varsigma$.

72. Whelan $(1993,69)$ signale: «Scholarly characterizations and depictions of Phoebe cross a broad spectrum, from those who affirm (or acknowledge the possibility of) an official role or authoritative status, to those who oppose it in varying degrees ».

73. Rife $(2010,424$, n. 78$):$ « [ $\pi \rho 0 \sigma \tau \alpha \dot{\tau} \iota \varsigma]$ is the feminine counterpart of $\pi \rho \circ \sigma \tau \alpha \dot{\tau} \tau \varsigma$. The usage of these Greek terms during the Roman era seems to have been the equivalent of the Latin patronus and patrona».

74. Outre la transcription du texte, on trouvera en Pallas et al. (1959) une traduction française de ces 85 lignes. Comme le rappelle Murphy O' Connor $(2004,111)$, «on ignore l'emplacement originel de cette stèle».

75. Kearsley $(1999,192)$ : «As Theodora is a Greek name [...] and it was a common habit of Greeks who were Roman citizens [...] to combine their new Roman names or name $[\ldots]$ with their original personal name $[. .$.$] , the conclusion that she was a$ woman of a Greek family or the product of a marriage between a Roman and a women of a prominent local family, is more likely".

76. Pallas et al. $(1959,503)$ : «Tous ces textes sont adressés aux Corinthiens afin qu'ils soient au courant de la reconnaissance témoignée à Iounia Théodora. [...] Nous ne la connaissons pas autrement, ni à Corinthe, ni en Lycie». 
Qu'apprend-on donc au sujet de Junia Théodora, cette femme «des plus considérées» (1.23), dont «on peut placer [l']activité dans les années 40, peut-être 50, du premier siècle de notre ère " (Murphy O' Connor $2004,111)^{77}$ ? Elle a été $\phi 1 \lambda$ o trois genres d'activité ». Outre qu'elle a offert l'hospitalité aux Lyciens de passage à Corinthe (1. 28.58-59.75-76) - des particuliers, des ambassadeurs (1. 48-51) ou des exilés (1. 58) —, elle leur «a assuré [...] l'appui des autorités romaines avec lesquelles elle était en excellentes relations» (1. 52-53) et a été encore pour les siens « une bienfaitrice» par voie testamentaire (1. 7-8.59) (Robert 1960, 326.330) (8) $^{7}$.

On peut en conséquence supposer que Phoebé, outre qu'elle accueillait chez elle la communauté de Cenchrées, recevait également les frères «de passage, qu'elle devait aider de ses avis, de ses contacts, et, en cas de besoin, de son intervention» (Murphy O' Connor 2004, 113). L'imaginer comme une «bienfaitrice» et une «patronnesse» est donc permis ${ }^{79}$.

77 Pallas et al. $(1959,506)$ estiment que les « inscriptions se situent vraisemblablement quelque peu après 43 [de notre ère], dans les limites déterminées par l'âge que pouvait avoir Iounia d'une part quand elle accueillait les Lyciens exilés, d'autre part au moment du vote des textes qui l'honorent ".

78 Kearsley $(1999,196)$ relève: «Iunia Theodora differs from the typical profile of a female civic patron. Instead of providing public buildings and financing the celebration of civic and religious activities, she developed a highly individual kind of patronage ».

79 Kearsley $(1999,202)$ estime: "There appears to be no reason on grounds of sex alone to deny [to Phoebe] the role of the benefactor of Paul and the Christians living in Kenchreai. A general similarity in her role to that of Theodora at Corinth on behalf of the Lycians, for instance, may well be indicated by the appearance in the decree of Telmessos of the form $\pi \rho 0 \sigma \tau \alpha \sigma i \alpha \nu$ (1. 77)». 


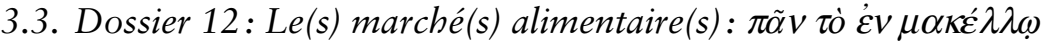

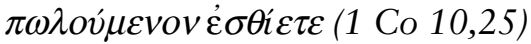

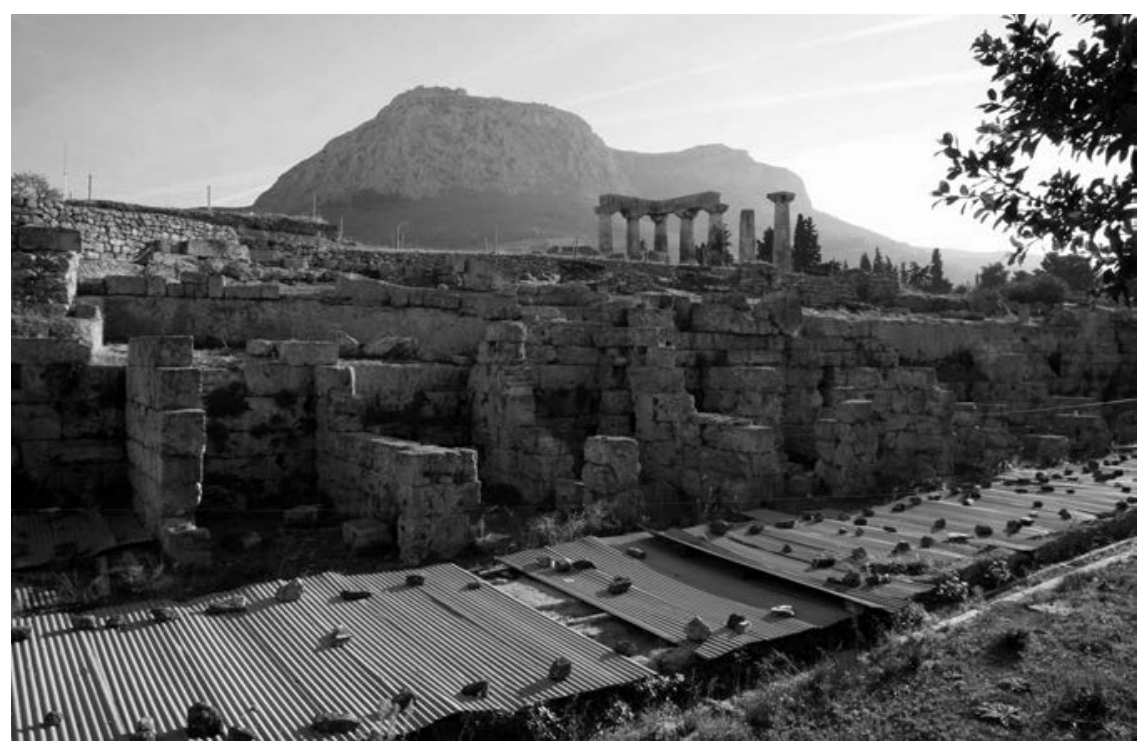

Photo prise par l'auteur

Il est généralement admis que le macellum ${ }^{80}$ était un lieu fréquenté surtout par une clientèle aisée, étant donné la qualité et, donc, le prix des produits vendus. Les acheteurs de condition relativement modeste, plus rares, n'y venaient que lorsqu'il leur fallait organiser un repas de fête ${ }^{81}$. La question particulière de son approvisionnement en viande est, quant à elle, plus discutée $^{82}$. S'il est indéniable qu'une partie au moins des pièces carnées pro-

80. De Ruyt $(1983,341)$ observe: «Le macellum était un marché exclusivement alimentaire. [...] On y trouvait surtout des denrées riches [...]. C’est précisément cette spécialisation dans les produits de qualité [...] qui lui valut son surmom de Forum cuppedinis, le marché des gourmets ». Koch $(1999,198)$ précise : «Im Unterschied zu einer normalen Handelsagora, auf der grundsätzlich Waren aller Art zum Verkauf kamen, diente das macellum einem sehr spezialisierten Warenangebot. Aus literarischen, epigraphischen und archäologischen Zeugnissen lässt sich eindeutig entnehmen, dass in einem macellum besonders hochwertige Nahrungsmittel angeboten wurden, nämlich Fleisch, Fisch, Geflügel, Wild, besonders teures Gemüse oder auch Obst. Hier konnte man alles bekommen, was man benötigte, wenn man eine standesgemässe Einladung, ein anspruchsvolles Gastmahl veranstalten wollte».

81. Pour la clientèle du macellum, voir De Ruyt (1983, 369-372).

82. Klauck, $(1982,274)$ demande: "Stammt alles Fleisch auf dem Markt von Opfertieren? [...] War [...] in der hellenistischen Umwelt Fleisch und Opferfleisch dasselbe ? » 
venaient de sacrifices, trouvait-on aussi au macellum de la viande ordinaire? L'enquête menée par Dietrich-Alex Koch (1999) tend à le confirmer ${ }^{83}$. Pour autant, le client était-il toujours en mesure d'être renseigné sur la provenance des produits? Il est difficile de l'affirmer.

Sachant que «la plupart des villes romaines ne comprenaient qu'un seul macellum », ou tout au plus «un très petit nombre » (De Ruyt 1983, 341), le(s)quel(s) parmi les quatre sites actuellement envisageables ${ }^{84}$ peu(ven)t-il(s) être identifié(s) en tant que lieu(x) d'un macellum se tenant vers 50 de notre ère? Cette question a été passablement discutée ${ }^{85}$.

Deux des structures retenues semblent devoir être écartées: celle située au nord de la basilique qui longe la route de Lechaion (Williams II 1993, 40-41) et celle découverte à l'ouest de la colline du temple (Williams II 1993, 44-45), la première en raison de l'incertitude au sujet de sa fonction exacte avant le tremblement de terre de 77 ÈC ${ }^{86}$, la seconde parce qu'elle est située trop à l'écart des voies de desserte des deux ports de Corinthe ${ }^{87}$. Restent le marché qui existait vraisemblablement jusqu'au tremblement de terre de 77 sur l'emplacement du péribole d'Apollon jouxtant la fontaine Peirène (Williams II 1993, 39-40) et celui situé au nord du temple archaïque, construit entre 25 et 50 ÈC (Scranton 1951, 180-188; De Ruyt 1983, 56-59; Williams II 1993, 41-44). En faveur du premier, on peut mettre en avant son plan initial caractéristique et les inscriptions retrouvées ${ }^{88}$. Pour

83. Koch $(1999,213)$ : «Es zeigt sich [...], dass das Fleisch, das im macellum zum Verkauf kam, für den Käufer in der Tat von unklarer Herkunft war - es konnte sich tatsächlich um beides handeln, um normales Fleisch, also Fleisch von Tieren, die nicht für Opfervorgänge geschlachtet worden waren, und um Fleisch, das aus kultischen Schlachtungen stammte». Et d'ajouter, p. 214: "Doch ist es unwahrscheinlich, dass der Gesamtbedarf in einer Stadt wie Korinth regelmässig überwiegend aus Opferschlachtungen gedeckt werden konnte».

84. Pour un bref rapport sur ces quatre sites, voir Williams II (1993, 31-46).

85. C'est ce que relève De Ruyt $(1983,60)$; voir déjà Cadbury (1934).

86. Williams II $(1993,41)$ exprime ainsi sa réserve: «It may be questionned, however, whether the hemicycle in its original form really was a produce market ».

87. Ainsi Williams II (1993, 41). L'auteur avance l'hypothèse selon laquelle ç'aurait été un entrepôt de produits locaux.

88. Williams II $(1993,39)$ : "The early plan is similar to that of a meat and fish market at Pompeii. [...] Fragments [...] dated by their letter form to the Augustan period [...] refer to a macellum and macellum piscarum [...]. If this court is the macellum of the inscription, then it is likely that this circular foundation would have supported the fish market, sometimes called a tholos". 
l'identification du second en tant que macellum plaident sa forme ${ }^{89}$ et son alimentation en eau ${ }^{90}$, ceci malgré la réserve émise par Williams II ${ }^{91}$.

\section{En guise de conclusion}

Cette enquête pourrait être étendue à d'autres dossiers encore. Au moment de l'arrêter, rappelons que notre principal objectif était d'en consulter certains parmi les plus ouverts, afin d'évaluer dans quelle mesure les fouilles réalisées et les interprétations qu'en proposent les spécialistes du langage des pierres peuvent effectivement éclairer certaines pages de la première lettre de Paul aux Corinthiens. De cette rapide approche, nous tirons deux conclusions élémentaires: 1 ) il convient de scruter très attentivement les rapports de fouilles et, surtout, de suivre les débats qu'ils suscitent entre gens du métier avant d'en tirer, en tant qu'exégète, de prudentes hypothèses pour expliquer le texte lu;2) dans la mesure où l'archéologie ne dégage plus seulement le cadre de vie dans lequel des hommes et des femmes ont construit leur identité en Christ, mais nous renseigne encore sur la manière dont on vivait jadis dans la cité isthmique, il serait dommage de se priver d'utiles informations sur la vie quotidienne à Corinthe au milieu du premier siècle de notre ère.

"To move from geographically restricted archaeological information to the interpretation of a New Testament writing is a complex and difficult, perhaps even impossible, venture» avertit Helmut Koester (1990, 441). S'il est vrai qu'il n'est pas facile d'interroger l'archéologie sur des points relevant plus de l'anecdote, nous lui sommes toutefois reconnaissants pour les fenêtres qu'elle ouvre sur quelques passages particuliers de la première lettre de Paul aux Corinthiens ${ }^{92}$.

89. Scranton $(1951,192)$ note: «The Market has been so designated without hesitation from its first discovery. Its plan [...] is obviously similar to that of the Roman macellum $[\ldots]$ : a peristyle court surrounded by shops ".

90. De Ruyt $(1983,61)$ compte au nombre des indices incitant à reconnaître dans le marché nord un macellum «l'aménagement complexe du réseau d'égouts sous les portiques et à l'intérieur des boutiques".

91. Williams II $(1993,42)$ : «One might best assume that the rooms served as officies, rather than as shops that sold or distributed green goods, meat, and fish ».

92 Parmi les publications parues entre le dépôt du manuscrit et la correction des épreuves - mais dont nous n'avons plus pu tenir compte -, signalons: Brookins (2013); Friesen (2014); Friesen, James et Schowalter (2014); Jacquemin, Mulliez et Rougemeont (2012); Nasrallah (2014); Stroud (2013); Stroud (2014) 


\section{Références}

BAslez, M.-F. (2010), «Paul et l'histoire. Nouvelles approches. État des questions ", Transversalités, 114, p. 31-48.

Bookidis, N. et Stroud, R.S. (1997), Corinth XVIII,3. The Sanctuary of Demeter and Kore. Topography and Architecture, Princeton, The American School of Classical Studies at Athens.

Bookidis, N. (2005), « Religion in Corinth: 146 B.C.E. to 100 C.E. », dans D. N. Schowalter et S. J. Friesen, dir., Urban Religion in Roman Corinth: Interdisciplinary Approaches, Cambridge, Harvard University Press (Harvard Theological Studies 53), p. 141-164.

Brändl, M. (2006), Der Agon bei Paulus. Herkunft und Profil paulinischer Agonmetaphorik, Tübingen, Mohr Siebeck (WUNT 2/222).

Broneer, O. (1962), "The Apostle Paul and the Isthmian Games ", The Biblical Archaeologist, 25, p. 2-31.

Brookins, T. A. (2013), "The (In)frequency of the Name "Erastus" in Antiquity. A Literary, Papyrological, and Epigraphical Catalog ", New Testament Studies, 59, p. 496-516.

Cadbury, H. J. (1931), «Erastus of Corinth», Journal of Biblical Literature, 50, p. 42-58.

(1934), "The Macellum of Corinth ", Journal of Biblical Literature, 53, p. 134-141.

Deissmann, A. (1923), Licht vom Osten. Das Neue Testament und die neuentdeckten Texte der hellenistisch-römischen Welt, Tübingen, Mohr (Siebeck).

De Ruyt, C. (1983), Macellum: marché alimentaire des Romains, Louvainla-Neuve, Institut supérieur d'archéologie et d'histoire de l'art (Publications d'histoire de l'art et d'archéologie de l'Université catholique de Louvain 35).

De Waele, F. J. (1933), "The Sanctuary of Asklepios and Hygieia at Corinth ", American Journal of Archaelogy, 37, p. 417-451.

(1935), "The Fountain of Lerna and the Early Christian Cemetery at Corinth ", American Journal of Archaelogy, 39, p. 352-359.

Fotopoulos, J. (2006), "The Misidentification of the Lerna Fountain at Corinth: Implications for Interpretations of The Corinthian Idol-Food Issue (1 Cor 8,1 - 11,1)", dans The New Testament and Early Christian Literature in Greco-Roman Context. Studies in Honor of David E. Aune, Leiden, Brill, p. 37-50. 
Foucart, M. P. (1867), Mémoire sur l'affranchissement des esclaves par forme de vente à une divinité d'après les inscriptions de Delphes, Paris, Imprimerie impériale.

Friesen, S. J. (2010), «The Wrong Erastus. Ideology, Archaeology, and Exegesis ", dans S. J. Friesen, D. N. Schowalter et J. C. Walters, dir., Corinth in Context: Comparative Studies on Religion and Society, Leiden, Brill (Supplements to Novum Testamentum 134) , p. 231-256.

(2014), «Junia Theodora of Corinth: Gendered Inequalities in the Early Empire», dans S. J. Friesen, S. A. James et D. N. Schowalter, dir., Corinth in Contrast: Studies in Inequality, Leiden, Brill (Supplements to Novum Testamentum 155), p. 203-226.

Friesen, S. J., James, S. A. et Schowalter, D. N., dir., (2014), Corinth in Contrast: Studies in Inequality, Leiden, Brill (Supplements to Novum Testamentum 155).

Friesen, S. J., Schowalter, D. N. et Walters, J. C., dir. (2010), Corinth in Context: Comparative Studies on Religion and Society, Leiden, Brill (Supplements to Novum Testamentum 134).

Freyne, S. (2006), "Jésus le Galiléen à l'épreuve de l'archéologie », dans J. H. Charlesworth, J. K. Elliott, S. Freyne et J. Reumann, Jésus et les nouvelles découvertes de l'archéologie, Paris, Bayard, p. 67-94.

Furnish, V. P. (1988), "Corinth in Paul's Time. What Can Archaeology Tell Us? ", Biblical Archaeology Review, 15, p. 15-27.

Gebhard, E. R. (1993), «The Isthmian Games and the Sanctuary of Poseidon in the Early Empire ", dans T. E. GRegory, dir., The Corinthia in the Roman Period, An Arbor, Journal of Roman Archaeology (Journal of Roman Archaeology. Supplementary Series 8), p. 78-94.

Grobel Miller, S. (1972), «A Mosaic Floor from a Roman Villa at Anaploga », Hesperia, 41, p. 332-354.

Hill, A. E. (1980), «The Temple of Asklepius. An Alternative Source for Paul's Body Theology ? ", Journal of Biblical Literature, 99, p. 437-439.

Horrell, D.G. (2004), «Domestic Space and Christian Meeting at Corinth. Imagining New Contexts and the Buildings East of the Theatre », New Testament Studies, 50, p. 349-369.

Jacquemin, A., Mulliez, D. et Rougemont G., dir., (2012), Choix d'inscriptions de Delphes, traduites et commentées, École française d'Athènes (Études Épigraphiques 5), p. 234-249. 
Kent, J. H. (1966), Corinth VIII,3. The Inscriptions (1926-1950), Princeton, The American School of Classical Studies at Athens.

Kearsley, R. A. (1999), "Woman in Public Life in the Roman East: Iunia Theodora, Claudia Metrodora and Phoebe, Benefactress of Paul ", Tyndale Bulletin, 50, p. 189-211.

Klauck, H.-J. (1982), Herrenmahl und hellenistischer Kult. Eine religionsgeschichtliche Untersuchung zum ersten Korintherbrief, Münster, Aschendorff (Neutestamentliche Abhandlungen. Neue Folge 15).

КосH, D.-A. (1999), " “Alles, was $\dot{\varepsilon} \vee \mu \alpha \kappa \varepsilon ́ \lambda \lambda \omega$ verkauft wird, esst ...”. Die macella von Pompeji, Gerasa und Korinth und ihre Bedeutung für die Auslegung von 1 Kor 10,25 ", Zeitschrift für die Neutestamentliche Wissenschaft und die Kunde der älteren Kirche, 90, p. 194-219.

Koester, H. (1990), «From Paul's Eschatology to the Apocalyptic Schemata of 2 Thessalonians", dans R. F. Collins, dir., The Thessalonians Correspondance, Leuven, University Press (Bibliotheca Ephemeridum Theologicarum Lovaniensium 87), p. 441-458.

(2005), "The Silence of the Apostle», dans D. N. Schowalter et S. J. Friesen, dir., Urban Religion in Roman Corinth: Interdisciplinary Approaches, Cambridge, Harvard University Press (Harvard Theological Studies 53), p. 339-349.

LANGRIdge-Noti, E. (1996), A Corinthian Scrapbook. One Hundred Years of American Excavations in Ancient Corinth, Athens, Lycabetus Press.

Lehö̈rfF, A. $\left(2009^{3}\right)$ [2002], "Le travail de terrain », dans J. P Demoule, et al., Guide des méthodes de l'archéologie, Paris, La Découverte (Repères), p. 40-90.

Meggitt, J. J. (1998), Paul, Poverty and Survival, Edinburgh, T\&T Clark.

MeritT, B. D. (1931), Corinth VIII,1. Greek Inscriptions (1896-1927), Princeton, The American School of Classical Studies at Athens.

Murphy O’Connor, J. (2004), Corinthe au temps de Saint Paul. L'archéologie éclaire les textes, Paris, Cerf.

Nasrallah, L. S. (2014), " "You Were Bought with a Price": Freedpersons and Things in 1 Corinthians ", dans S. J. Friesen, S. A. James et D. N. Schowalter, dir., Corinth in Contrast: Studies in Inequality, Leiden, Brill (Supplements to Novum Testamentum 155), p. 54-73.

Oster, R. E. (1992), «Use, Misuse and Neglect of Archeological Evidence in Some Modern Works on 1 Corinthians (1 Cor 7,1-5; 8,10; 11,2-16; 
12,14-26) », Zeitschrift für die Neutestamentliche Wissenschaft und die Kunde der älteren Kirche, 83, p. 52-73.

Pallas, D. I., Charitodinis, S. et Venencie, J. (1959), "Inscriptions lyciennes trouvées à Solômos près de Corinthe ", Bulletin de correspondance bellénique, 83, p. 496-508.

Prigent, P. (2002), L'épître aux Romains, Genève/Paris, Labor et Fides/ Bayard (Bible en face).

Rife, J. L. (2010), "Religion and Society at Roman Kenchreai», dans S. J. Friesen, D. N. Schowalter et J. C. Walters, dir., Corinth in Context: Comparative Studies on Religion and Society, Leiden, Brill (Supplements to Novum Testamentum 134), p. 391-432.

Robert, L. (1960), "Recherches épigraphiques", Revue des Études Anciennes, 62, p. 276-361.

Robinson H. S. (1965), "Excavations at Ancient Corinth (1959-1963)", Klio. Beiträge zur alten Geschichte, 46, p. 289-305.

Roebuck, C. (1951), Corinth XIV. The Asklepieion and Lerna, Princeton, The American School of Classical Studies at Athens.

Roux, G. (1958), Pausanias en Corinthie (Livre II, 1 à 15), Paris, Les Belles Lettres (Annales de l'Université de Lyon 31).

SANDers, G. D. R. (2005a), «Urban Corinth: An Introduction », dans D. N. Schowalter et S. J. Friesen, dir., Urban Religion in Roman Corinth: Interdisciplinary Approaches, Cambridge, Harvard University Press (Harvard Theological Studies 53), p. 11-24.

(2005b), «Archeological Evidence for Early Christianity and the End of Hellenic Religion in Corinth", dans D. N. Schowalter et S. J. Friesen, dir., Urban Religion in Roman Corinth: Interdisciplinary Approaches, Cambridge, Harvard University Press (Harvard Theological Studies 53), p. 419-442.

Schnapp, A. $\left(2009^{3}\right)$ [2002], «Histoire de l'archéologie et l'archéologie dans l'histoire», dans J.-P. Demoule et al., Guide des méthodes de l'archéologie, Paris, La Découverte (Repères), p. 9-39.

Schowalter, D. N. (2010), "Seeking Shelter in Roman Corinth. Archaeology and the Placement of Paul's Communities ", dans S. J. Friesen, D. N. Schowalter et J. C.Walters, dir., Corinth in Context: Comparative Studies on Religion and Society, Leiden, Brill (Supplements to Novum Testamentum 134), p. 327-341. 
Schowalter, D. N. et Friesen, S. J., dir. (2005), Urban Religion in Roman Corinth: Interdisciplinary Approaches, Cambridge, Harvard University Press, (Harvard Theological Studies 53).

SCRANTON, R. L. (1951), Corinth I,3. Monuments in the Lower Agora and North of the Archaic Temple, Princeton, The American School of Classical Studies at Athens.

Stroud, R. S. (1993), "The Sanctuary of Demeter on Acrocorinth in the Roman Period ", dans T. E. Gregory, dir., The Corinthia in the Roman Period, An Arbor, Journal of Roman Archaeology (Journal of Roman Archaeology. Supplementary Series 8), p. 65-77.

(2013), The Sanctuary of Demeter and Kore: The Inscriptions, Princeton, The American School of Classical Studies at Athens.

(2014), "Religion and Magic in Roman Corinth", dans S. J. Friesen, S. A. James et D. N. Schowalter, dir., Corinth in Contrast: Studies in Inequality, Leiden, Brill (Supplements to Novum Testamentum 155), p. 187-202.

Theissen, G. (1996), «La stratification sociale de la communauté corinthienne", dans Histoire sociale du christianisme primitif. Jésus - Paul - Jean, Genève, Labor et Fides (Le Monde de la Bible 33), p. 91-138.

Thiselton, A. C. (2000), The First Epistle to the Corinthians, Grand Rapids, Eerdmans (NIGTC).

(2006) «The Significance of Recent Research on 1 Corinthians for Hermeneutical Appropriation of this Epistle Today ", Neotestamentica, 40, p. $320-352$.

Walters, J. C. (2010), «Paul and the Politics of Meals in Roman Corinth», dans S. J. Friesen, D. N. Schowalter et J. C. Walters, dir., Corinth in Context: Comparative Studies on Religion and Society, Leiden, Brill (Supplements to Novum Testamentum 134), p. 343-364.

Whelan, C.F. (1993), "Amica Pauli: The Role of Phoebe in the Early Church ", Journal for the Study of the New Testament, 49, p. 67-85.

Williams II, C. K. (1993), "Roman Corinth as a Commercial Center ", dans T. E. Gregory, dir., The Corinthia in the Roman Period, An Arbor, Journal of Roman Archaeology (Supplementary Series 8), p. 31-46.

(2005), «Roman Corinth: the Final Years Pagan Cult Facilities along East Theater Street", dans D.N. Schowalter et S.J. Friesen, dir., Urban Religion in Roman Corinth: Interdisciplinary Approaches, Cambridge, Harvard University Press (Harvard Theological Studies 53), p. 221-247. 
Williams II, C. K. et Bookidis, N., dir. (2003), Corinth, the Centenary (1896-1996), Princeton, The American School of Classical Studies at Athens.

Williams II, C. K. et Zervos, O. H. (1984), «Corinth, 1983: The Route to Sikyon ", Hesperia, 53, p. 83-122.

(1986), "Corinth, 1985 : East of the Theater ", Hesperia, 55, p. $129-175$.

(1988), "Corinth, 1987: South of Temple E and East of the Theater ", Hesperia, 57, p. 95-146.

Winter, B. W. (2001), After Paul Left Corinth. The Influence of Secular Ethics and Social Change, Grand Rapids, Eerdmanns.

Wiseman, J. (1970), "The Fountain of the Lamps ", Archaeology, 23, p. $130-137$.

(1980), "Corinth and Rome I: 228 B.C. - A.D. 267 », ANRW II,7,1, Berlin / New York, De Gruyter, p. 438-548.

Witherington III, B. (1995), Conflict and Community in Corinth: A Socio-Rhetorical Commentary on 1 and 2 Corinthians, Grand Rapids, Eerdmans.

\section{Résumé}

Quel profit y a-t-il à interroger l'archéologie pour commenter la première lettre de Paul aux Corinthiens, alors même que les communautés pauliniennes des premiers temps n'ont pas laissé de traces visibles de leur existence? Une reprise critique de douze dossiers-test, s'appuyant entre autres sur les actes de travaux interdisciplinaires publiés en 2005 et en 2010, tente de répondre à cette question relancée en 1983 par Jerome Murphy O'Connor. Si l'éclairage qu'apporte l'archéologie sur l'épître envoyée à ceux qui construisaient leur identité en Christ dans la cité isthmique vers le milieu du premier siècle est le plus souvent indirect, son apport est cependant loin d'être négligeable, dans la mesure où cette discipline s'intéresse aujourd'hui également au quotidien des petites gens.

\section{Abstract}

What profit is there to turn to archaeology to comment on Paul's First Corinthians when the first Pauline communities did not leave visible signs of their existence? A critical assessment of 12 test-cases based-among 
other things-on interdisciplinary researches published from 2005 to 2010 tries to answer this question raised in 1983 by Jerome Murphy O'Connor. If the light that archaeology sheds on this epistle that was sent to those who were building their identity in Christ in the isthmic city around the middle of the first century shines often indirectly, its contribution is far from being negligible - considering this discipline takes great interest today in the common people's everyday lives. 